\title{
NEUTRALIZING ANTIBODY RESPONSES OF GUINEA-PIGS TO INACTIVATED RUBELLA VIRUS VACCINE
}

\author{
BY DR. JACK W. FRANKEL
}

Research Department, ClBA Pharmaceutical Co., Summit, New Jersey

\section{A} NUMBER of investigators have recently reported the isolation of rubella virus in tissue cultures inoculated with specimens from patients with clinically diagnosed rubella. Parkman, Buescher and Artenstein ${ }^{1}$ observed that inoculation of primary African green monkey kidney cell monolayers with rubella virus rendered the cells resistant to super-infection with ECHO 11 virus. Sever, Schiff and Traub ${ }^{2}$ used Coxsackie $A-9$ virus for challenge. Weller and Neva ${ }^{3}$ noted specific cytopathogenic changes in cultures of primary human amnion cells infected with rubella virus. Utilizing these techniques, rubella virus isolations were afterwards reported by Veronelli, Maassab and Hennessy ${ }^{4}$, Sigurdardottir, Givan, Rozee and Rhodes ${ }^{5}$, Plotkin, Dudgeon and Ramsay ${ }^{6}$, Lehmann and Ferris ${ }^{7}$, Forbes, Bennett and Gray $^{8}$, Selzer ${ }^{8}$ and Heggie and Robbins ${ }^{10}$.

This article describes the frequency of isolation of rubella virus from naval recruits with clinically diagnosed disease and the neutralizing antibody responses of guinea-pigs following vaccination with non-viable rubella virus vaccine prepared from one of the rubella virus isolates.

Specimens were collected during A.pril 1962 from naval recruits with clinically diagnosed rubella (lymphadeno. pathy, general malaise, nausea, headache and erythematous macular or maculopapular eruption persisting for 2-4 days) within $24 \mathrm{~h}$ after onset of rash. Control specimens were collected from some patients in the midst of the rubella outbreak with complaints other than rubella (that is, rubeola), and throat washings were obtained from a number of 'rubella-contacts' who failed to exhibit any clinical evidence of disease. The throat washings (in 0.5 per cent lactalbumin hydrolysate-Hanks's balanced salt mixture) were stored at $-60^{\circ} \mathrm{C}$ in sealed glass ampules. Serum samples were collected at the same time and approximately 3 weeks later.

Rubella virus isolations were accomplished in culture tubes containing monolayers of African green monkey kidney cells. The monolayers were prepared, following treatment of kidneys with trypsin, with 2 per cent heatinactivated 'Agamma' calf serum *-Medium 199 mixture containing $\mathrm{SV}_{5}$ antiserum, and the monolayers, when confluent, were maintained with Medium 199. All media contained 1,000 units of penicillin and 1,000 $\mu \mathrm{g}$ of streptomycin per ml. No fewer than 10 cultures were inoculated with $0.1 \mathrm{ml}$. of throat washings and incubated on a roller apparatus at $36^{\circ} \mathrm{C}$. After $7-9$ days, a $p \mathrm{H}$ adjustment was made by the addition of small quantities of 2.4 per cent $\mathrm{NaHCO}_{3}$. After 12-15 days, fluids were pooled and frozen at $-60^{\circ} \mathrm{C}$ and $1.0 \mathrm{ml}$. of Medium 199 containing 100 TCD $D_{50}$ per $0 \cdot 1 \mathrm{ml}$. of Coxsackie $A-9$ virus added to each tube. The cultures were incubated for an additional 7 days and resistance of the monolayers to super-infection with challenge virus was considered presumptive evidence for the presence of rubella virus. At least 3 sub-passages of pooled culture fluids were made before a specimen was considered not to contain rubella virus.

Rubella virus infectivity titrations were performed by the inoculation of $0.1 \mathrm{ml}$. of serial $0.5 \log _{10}$ dilutions of rubella virus in Medium 199 to each of 4 culture tubes. After 12 days, the fluids were replaced with $1.0 \mathrm{ml}$. of

* Obtained from Hyland Laboratories, Los Angeles, California.
Medium 199 containing $100 T C D_{50}$ per $0.1 \mathrm{ml}$. of Coxsackie $A-9$ virus. Infectivity titres (TCD 50 per $0.1 \mathrm{ml}$.) were recorded 5 days later as the highest dilution of rubella virus rendering cells resistant to Coxsackie $A-9$ virus super-infection. Along with infectivity titrations, as with rubella virus isolations and sub-passages, uninoculated culture fluids were passed. Hæmadsorption tests with a variety of erythrocytes and animal and chicken embryonated egg inoculations were frequently made to exclude the presence of agents other than rubella virus.

Neutralizing antibody titres were determined by incubating $0.5 \mathrm{ml}$. quantities of serial ten-fold dilutions of rubella virus (diluted in $\mathbf{0 . 5}$ per cent 'Agamma' calf serumMedium 199 mixture) with $0.5 \mathrm{ml}$. of serial two-fold dilutions of unheated serum for $90 \mathrm{~min}$ at room temperature. $0.2 \mathrm{ml}$. of mixture was then inoculated into each of 3 culture tubes and the monolayers incubated at $36^{\circ} \mathrm{C}$ for 11 days. After fluid removal, $1.0 \mathrm{ml}$. of Medium 199 containing $100 T C D_{50}$ per $0.1 \mathrm{ml}$. of Coxsackie $A-9$ virus was added to each tube. Five days later, neutralizing antibody titres were recorded as the highest (original) dilution of serum capable of suppressing the control rubella virus infectivity titre at least ten-fold $\left(10^{-4.1}\right.$ $10^{-8.1}$ per $0 \cdot 1 \mathrm{ml}$. in Table 1 ).

Tablc 1. NeUTradizing ANTIBODy Titres in Guinea-pigs to RUBelLA Tablc 1. NEUTRALIZING ANTIBODY TMRES IN

\begin{tabular}{|c|c|c|c|c|c|c|c|c|}
\hline \multirow[b]{2}{*}{ Animal } & \multirow[b]{2}{*}{$0^{*}+$} & \multicolumn{6}{|c|}{ Weeks and antibody titre (reciprocal) } & \multirow[b]{2}{*}{$20 \uparrow$} \\
\hline & & $1 *$ & $2^{*}$ & $3 \dagger$ & 7 & $13 *$ & 16 & \\
\hline 1 & $<4$ & $<4$ & $<4$ & 128 & 64 & 16 & 32 & 32 \\
\hline 2 & $<4$ & $<4$ & 64 & 512 & 512 & 64 & 256 & 128 \\
\hline 3 & $<4$ & $<4$ & $<4$ & $<4$ & $<4$ & $<4$ & $<4$ & $<4$ \\
\hline 4 & $<4$ & $<4$ & 32 & 64 & 32 & 4 & 64 & 256 \\
\hline 5 & $<4$ & $<4$ & 64 & 64 & 32 & 16 & 128 & 32 \\
\hline 6 & $<4$ & $<4$ & $<4$ & $<4$ & $<4$ & $<4$ & 16 & 16 \\
\hline 7 & $<4$ & & & 32 & 64 & 8 & 64 & 32 \\
\hline 8 & $<4$ & & & 250 & 64 & 16 & 128 & 128 \\
\hline 9 & $<4$ & & & 32 & 64 & 8 & 256 & 64 \\
\hline 10 & $<4$ & & & 128 & 512 & 32 & 32 & 32 \\
\hline 11 & $<4$ & & & 64 & 4 & 32 & 256 & 64 \\
\hline , M. & & & & $1: 45$ & $1: 34$ & $1: 11$ & $1: 60$ & $: 4$ \\
\hline
\end{tabular}

* Intramuscular injection of $1.0 \mathrm{ml}$. vaccine.

+ Serum $(1: 4)$ failed to neutralize Coxsackie $A-9$ virus. $\$$ Geometric mean of neutralizing antibody titres.

The rubella virus vaccine was prepared as follows: 1-1. capacity bottles containing confluent African green monkey kidney cell monolayers maintained with $65 \mathrm{ml}$. of Medium 199 were inoculated with $1.5 \mathrm{ml}$. of undiluted rubella virus (isolate $G L 6,3$ rd monkey kidney culture passage, $10^{2.8} T C D_{50}$ per $0.1 \mathrm{ml}$.) and incubated for 13 days at $36^{\circ} \mathrm{C}$, during which time the $p \mathrm{H}$ was occasionally adjusted with dilute $\mathrm{NaHCO}_{3}$. The cells and fluids were frozen in an alcohol-dry ice mixture, thawed once, pooled and centrifuged at 2,000 r.p.m. at $5^{\circ} \mathrm{C}$ for $30 \mathrm{~min}$. The $p H$ of the pool was adjusted to $7 \cdot 2$ and inactivation of virus infectivity $\left(10^{8.8} T C D_{50} / 0.1 \mathrm{ml}\right.$.) was directly performed with liquid ethylene oxide at a final concentration of 1 per cent for $1 \mathrm{~h}$ at $5^{\circ} \mathrm{C}$. The ethylene oxide was completely volatilized during further incubation at $36^{\circ} \mathrm{C}$ for $14 \mathrm{~h}$. The vaccine was stored at $5^{\circ} \mathrm{C}$ for the duration of the investigation. The vaccine probably did not contain any viable rubella virus or any other viruses since inoculation of monkey kidney cell cultures with the vaccine and subsequent challenge of some 
cultures with 500-1,000 $T C D_{50}$ per $0.1 \mathrm{ml}$. of Coxsackie $A-9$ virus failed to reveal the presence of such agents. Two additional sub-passages yielded similar results as did a single test performed in rabbit kidney cell monolayers according to the technique reported by MeCarthy, Taylor-Robinson and Pillinger ${ }^{11}$. Suckling mice and chicken embryonated eggs were inoculated with the vaccine, also. Tests for detection of viable microbes other than viruses were similarly negative.

The results of virus isolation investigations indicate that the frequency of rubella virus isolation was greater from throat washings collected $1-12$ rather than $13-24 \mathrm{~h}$ after rash onset. From 30 clinically diagnosed cases of rubolla, 18 rubella virus isolates were obtained: 10/12 (83 per cent) from throat washings collected $1-12 \mathrm{~h}$ and 8/18 (44 per cent) from specimens collected 13-24 h following onset of rash. Rubella virus was recovered from 1 of 14 'rubella contacts' and rubeola virus from 2 individuals with illnesses clinically diagnosed as measles. Each rubella virus isolate was further characterized in that: (1) none was neutralized by homologous- or heterologous-acute phase serum samples but each was crossneutralized by 3 -week convalescent sera (antibody titres $1 / 32-1 / 512) ;(2)$ the infectivity of each isolate was neutralized by 4 pools of human $\gamma$-globulin $\uparrow$ (antibody titres 1/128->1/512); (3) each was neutralized by a standard reference rubella virus antiserum: (antibody titres $1 / 16-1 / 1,024) ;(4)$ all the convalescent but none of the acute phase serum samples neutralized a standard reference rubella virus preparation $\ddagger$ (antibody titres 1/64-1/1,024). Various virus hyperimmune antisera failed to react with any of the isolates in neutralization and complement-fixation tests. Based on these results, the rubella virus isolates appeared to be antigenically similar to, or identical with, one another and the reference rubella virus preparation.

To determine whether the vaccine would induce the formation of neutralizing antibodies, 11 male guinea-pigs weighing 600-700 $\mathrm{g}$ were injected intramuscularly with $1.0 \mathrm{ml}$. ( $0.5 \mathrm{ml}$. injected into each of 2 sites) of vaccine and serum was collected at intervals noted in Table 1 . Two additional animals as controls were inoculated with $1.0 \mathrm{ml}$. of normal tissue culture fluid treated with ethylene oxide. Neutralizing antibody titres were determined in a single neutralization test employing rubella virus isolate $G L 8$

$\uparrow$ Kindly supplied by Dr. J. Inman, Ortho Research Foundation, Raritan Niw Jersey.

+ Kindly supplied by Ir. G. Schiff, University of Cincinnati Medical School. rather than $G L 6$ used in the preparation of the vaccine. It can be seen from Table 1 that neither pre-vaccination sera nor serum specimens collected 1. week following a single injection of vaccine contained rubella virus antibodies. One week after a second injection of vaccine, neutralizing antibody titres were detected in 3 of 6 guineapig sera (antibody titres $1 / 32-1 / 64$ ). Significantly higher titres $(1 / 32-1 / 512)$ were found in serum samples collected 1 week after a third inoculation of vaccine (geometric: mean 1/34) and these titres appeared to decline within 10 weeks (geometric mean 1/11). However, a single injection of vaccine at this 10 -week interval resulted in an increase in the geometric mean of the neutralizing antibody titres to $1 / 60$. Moreover, this additional inoculation resulted in the seroconversion of one guinea-pig (No. 6). Antibodies were not detected in undiluted serum samples collected from another (No. 3). None of the sera collected from immunized and control animals neutralized Coxsackie A.9 virus.

The results of these investigations indicate that rubella virus neutralizing antibodies appear in sera of guinea-pigs following immunization with rubella virus vaccine not containing detectable viable rubella virus. Since infection with rubella virus may result in serious congenital malformations, the results suggest that vaccination of susceptible human beings with non-viable rubella virus vaccine may induce the formation of antibodies protective against this virus infection.

I thank Captain I. F. Miller (U.S.N.), Lieut. J. Maisel (U.S.N.R.), Dr. R. E. Jewett (University of Kansas Medical School), Mr. A. E. Cadilek (CIBA), Mr. O. F. Andersen (CIBA) and Mr. N. F. MeHugh (CIBA.) for their assistance. 'Parkman, P. D., Buescher, E. L., and Artensteil, M. S., I'roc. Soc. Exp.
Biol. and Med.,111, 225 (1962).

'Sever, J. L., Schiff, G. N., and Trauh, R. G., J. Amer. Med. Assuc.. 182, $663(1962)$.

${ }^{3}$ Weller, T. H., and Neva, F. A., Proc. Soc. Kxp. Biol. and Med., 111, 21: (1962).

- Veronelli, J. A., Masssab, H. F., and Hennessy, A. V., Proc. Soc. Exp. Biol. and Med., 11i, $472(1962)$

'Sigurdardottir, B., Givan, K. G., Rozee, K. R., and Rhodes, A. J, . Canac'. Med. A880c. J., 88, 128 (1963).

6 Plotkin, S. A., Dudgeon, J. A., and Ramsay, A. M., Brit. Med. I., ii, 1296 (1963).

'Lehmann, N. I., and Ferris, A. A., Med. J. Austral., 25, 1015 (1963). "Forbes, J. A., Bennett, N. McK., and Gray. N. J.. Med. J. Austial., 25,

- Selzer, G., Lancet, Ii, 336 (1963).

${ }^{10}$ Heggie, A. D., and Robbins, F. C., Pror. Soc. Exp. Biol. and Med., 114. 750 (1963).

"MeCarthy, K., Taylor-Robinson, C. H., and Jillinger, S. F., Jencet. ii. $593(1963)$.

\title{
RELATIONSHIP BETWEEN RADIATION DOSE AND GIANT CELLS IN THE SURVIVING CELL POPULATION OF MOUSE MARROW AS DETERMINED BY INTERFERENCE MICROSCOPY
}

\author{
By HUN LEE and Prof. VICTOR RICHARDS
}

\author{
Department of Surgery, Presbyterian Medical Center, San Francisco
}

$\mathrm{W}$ E have reported previously the dry mass distribution of the normal bone marrow cell population of the inouse ${ }^{1}$ and the subsequent changes during the first 24-h post-irradiation period ${ }^{2}$, and suggested that the dry mass changes might help to determine the degree of radiation injury of the marrow and the chances of survival of the patient. This article is the result of an investigation of the quantitative relationship between radiation doses and the changes in cellular dry mass of the giant cells in the surviving marrow cell population $24 \mathrm{~h}$ following irradiation. The changes, as we observed, are approximately proportional to the radiation dose; thus the information may be of value in the estimation of radiation injury to the marrow caused by a source known or unknown as to its strength.

$L A F_{1}$ male mice of approximately $20-33 \mathrm{~g}$ hody-wt. and about 8-9 weeks of age were supplied by Jackson Memorial Laboratory. Each animal was exposed to a single dose of total-body $\mathrm{X}$-irradiation $(200 \mathrm{kVp}, 20 \mathrm{~m}$.amp. high-voltage layer, $1.35 \mathrm{~mm}$ copper) in an individual plastic container. Some of these doses, namely, 1,000 and $1,500 \mathrm{r}$., were composed of two successive exposures with an interval between them of no more than $10 \mathrm{~min}$. Twenty-four hours after the irradiation, the animal was 